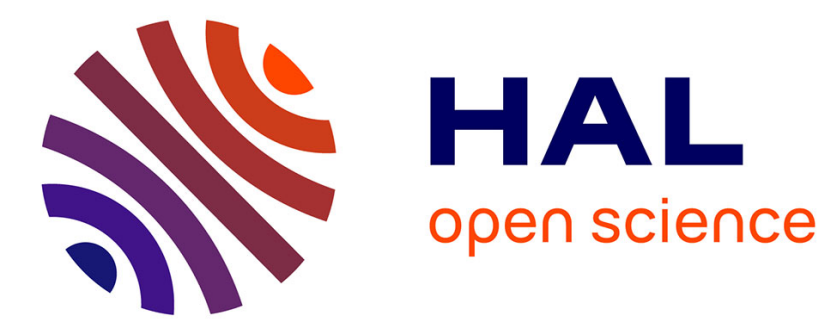

\title{
SPECTROSCOPIC DIAGNOSTICS OF A.D.C. NITROGEN PLASMA JET
}

Jean-Marie Baronnet, J. Rakowitz, J. Coudert, E. Bourdin, Pierre Fauchais, E. Pavlov

\section{- To cite this version:}

Jean-Marie Baronnet, J. Rakowitz, J. Coudert, E. Bourdin, Pierre Fauchais, et al.. SPECTROSCOPIC DIAGNOSTICS OF A.D.C. NITROGEN PLASMA JET. Journal de Physique Colloques, 1979, 40 (C7), pp.C7-247-C7-248. 10.1051/jphyscol:19797121 . jpa-00219093

\section{HAL Id: jpa-00219093 https://hal.science/jpa-00219093}

Submitted on 1 Jan 1979

HAL is a multi-disciplinary open access archive for the deposit and dissemination of scientific research documents, whether they are published or not. The documents may come from teaching and research institutions in France or abroad, or from public or private research centers.
L'archive ouverte pluridisciplinaire HAL, est destinée au dépôt et à la diffusion de documents scientifiques de niveau recherche, publiés ou non, émanant des établissements d'enseignement et de recherche français ou étrangers, des laboratoires publics ou privés. 


\title{
SPECTROSCOPIC DIAGNOSTICS OF A.D.C. NITROGEN PLASMA JET
}

\author{
J.M. Baronnet, J. Rakowitz, J.F. Coudert, E. Bourdin and P. Fauchais \\ Erchov*and E. Pavlov*. \\ Laboratoire de Thermodynamique, Université de Limoges, 87060 Limoges Cedex France. \\ * Institut de Physique, Minsk, Bielorussie, U.R.S.S.
}

Transition probabilities, Stark broadening and shift of NI have been measured and spectroscopic diagnostics of nitrogen plasma jet have been performed.

I. EXPERIMENTAL SET-UP. The jet is produced in a closed vessel $/ 1 /$. The anode arc channel is made of two parts (1)-(2) at the same electrical potential separated by a gap of $5 \mathrm{~mm}$ for spectroscopic observations of the arc. A BN ring (3) insulates the first anode from the second one (4). This device stabilizes the arc and permits analysis of the arc column, of the jet and of its plume.

The whole measurement : calibration, experimental data recording, and data treatment (Abel's inversion, restitution of spectral line profiles...) is performed with a data acquisition system connected to a computer.

II. TRANSITION PROBABILITES OF NI LINES AND STARK PARAMETERS MEASURED IN THE ARC. From stark broadening of $\mathrm{H} \alpha$ we have measured an electronic concentration of $1.05 \pm 0.1510^{17} \mathrm{~cm}^{-3}$ on the axis of the are - /2/ /3/; it had been previous1y shown that the line was not self - absorbed. We had also verified that $0.1 \mathrm{NI} / \mathrm{mn}$ of $\mathrm{H}_{2}$ mixed with nitrogen (volume ratio was $5 \%$ ) did not disturb the arc voltage or the microscopic properties of the plasma of interest (continuum emission at $495.5 \mathrm{~nm}$ and $493.5 \mathrm{~nm}$ line profile). Under these conditions L.C.T.E. is realized $/ 1 /$ according to the criterions of DRAWIN /4/; consequently, starting from the equilibrium composition we have determined a temperature of $13200 \pm$ $400 \mathrm{~K}$ and the concentration of $\mathrm{NI}: 3.4 \pm .410^{17}$ $\mathrm{cm}^{-3}$. From these measurements and those of volume emission coefficient we have determined the transition probabilities with a relative error of $50 \%$. (table I). Our results are in good agreement with those of MOTSCHMANN /5/ and RICHTER /6/. For the lines before $550 \mathrm{~nm}$ our results are $20 \%$ higher than those of MOTSCHMANN, even though WIESE has increased these last measures by more than $50 \%$. Calculations by GRIEM /8/ give results wich are generaly higher than the measured values.

We have especially studied the profiles of the 746.8 and $493.5 \mathrm{~nm}$ lines and determined their neutral collision shift and broadening/1/. Resonance broadening has been included for the $746.8 \mathrm{~nm}$ line.

We have neglected the Doppler effect for the $493.5 \mathrm{~nm}$ line profile, its Stark width $(2 \mathrm{w})$ and shift (d) being computed by fitting the experimental profile to a Lorentz profile. We have deduced the Stark parameters of the $746.8 \mathrm{nn}$ line by comparison of the experimental profile to profiles resulting from the convolution of a Döppler profile (at the temperature of measurement) with Lorentz profiles. The results are shown in figure II, where we have also quoted the values computed by $/ 9 /$ and $/ 10 /$; for $\mathrm{N}_{\mathrm{e}}$ between 5 and $1010^{16} \mathrm{~cm}^{-3}$ and $\mathrm{T}$ between $11500 \mathrm{~K}$ and $13500 \mathrm{~K}$ we propose the following : $2 \omega=8.210^{-3} \mathrm{~nm}, \mathrm{~d}=410^{-3} \mathrm{~nm}$ for $746,8 \mathrm{~nm}$ line and $2 \omega=1,9510^{-2} \mathrm{~nm}, d=2,810^{-3} \mathrm{~nm}$ for 493,5 nm line.

III. PLASMA JET DIAGNOSTICS. For the study of L.T.E. in the plasma jet $/ 4 /$ we have calculated the relaxation times of energy exchanges between the different degrees of freedom and we have determined the caracteristic times of relaxation to chemical equilibrium. The slower process is $\mathrm{N}_{2}$ dissociation $\left(N_{2}+M \rightarrow N+N+M\right)$; associative-ionization follows very rapidly $\left(N+N+N_{2}+e^{-}\right)$and then charge exchange $\left(\mathrm{N}_{2}^{+}+\mathrm{N} \rightarrow \mathrm{N}_{2}+\mathrm{N}^{+}\right)$occurs : Ionization by electronic collision is not really significant, but even with a low concentration $\mathrm{N}_{2}^{+}$is of major importance.

L.C.T.E. is only realized in the core where $\mathrm{N}_{e}$ is higher than $410^{15} \mathrm{~cm}^{-3}$ (T>8600K). Otherwise in the plune jet for example, vibration-vibration relaxation and dissociation times are great compared to hydrodynamic times. Anyhow, considering the very low relaxation times for rotation-rotation and rotation-transformation processes, rotational temperature of molecules is always equal to neutral 
translational temperature.

Consequently we have developped methods for the measurement of rotational temperature $/ 1 /$ and the following diagnostic method /11/ is proposed : the experimental profile is compared to theorical profiles computed under the assumption of L.C.T.E.. Volume emission coeficicients are calculated for all the rotation lines of the band under consideration (we assume that they are sufficiently narrow compared to the apparatus function and so are supposed to have a limited Dirac profile according to their intensities). We sum over the lines concerned, and perform a convolution with a triangular or Gaussian function. This is done for all of the bands of the sequence. The rotational temperature can be deduced from the rotational profile of the vibration hand even if L.C.T.E. is not realized. Furthermore this method emphazises the difference between the rotational and vibrational temperatures.

CONCLUSION. A computer driven data acquisition system has permitted the measurement of the transition probabilities of NI lines and also Stark parameters of the $746,8 \mathrm{~nm}$ and $493,5 \mathrm{~nm}$ lines. Furthermore we have shown that L.C.T.E. is not realized in the plume, consequent1y only the rotational temperature is representative of the translational temperature of neutrals.

REFERENCES

/1/ BARONNET J.M. Thèse de Doctorat ès Sciences. Limoges (1978).

/2/ HILI R.A. J.Q.S.R.T., 7, (1963), 82.

13/ WIESE W.E. et al., Phys. Rev., Al1, (1975), 1854

14/ DRAWIN H.W., High Pressure High Temperature, 2, (1970), 359.

/5/ MOTSCHMANN H., Z. Physik, 143, (1955), 77

16/. RICHTER J., Z. Astrophys., 51, (1961), 177.

17/ WIESE W.L. et a1., Atomic Transition Probabilities. Vo1. 1. NSRDS-NBS 4 (1966)

18/ GRIEM H.R., Plasma Spectroscopy, Mc Graw Hill (1964)

/9/ GRIEM H.R., Spectral line broadening by plasma, Academic Press (1974)

/10/ HELBIG v. et al., Phys. Rev., A14, (1976), 1082

/11/ COUDERT J.F., Thèse de 3ême cycle, Limoges, (1978).

\begin{tabular}{|cc|cc|cc|}
\hline$\lambda \mathrm{nm}$ & $\mathrm{A}_{\mathrm{si}}$ & $\lambda \mathrm{nm}$ & $\mathrm{A}_{\mathrm{si}}$ & \multicolumn{1}{|c|}{$\lambda \mathrm{nm}$} & ${ }^{\prime} \mathrm{A}_{\mathrm{si}}$ \\
\hline 870.326 & 200. & 742.364 & 50. & 517.000 & 1.9 \\
871.171 & 111. & 744.230 & 102. & 518.15 & 1.5 \\
871.884 & 53. & 746.831 & 159. & 518.69 & 0.8 \\
872.891 & 29. & 946.068 & 25. & 413.763 & 2.4 \\
874.736 & 7.2 & 856.774 & 74. & 414.342 & 5.1 \\
\hline 818.485 & 82. & 859.401 & 260. & 415.146 & 9.1 \\
818.801 & 125. & 862.924 & 250. & 541.188 & 8.9 \\
820.036 & 47. & 865.587 & 89. & 540.145 & 4.5 \\
821.071 & 48. & 902.892 & 188. & 438.440 & 4.2 \\
821.632 & 176. & 906.072 & 207. & 439.130 & 9.0 \\
822.312 & 214. & 491.490 & 6.0 & 422.304 & 3.8 \\
824.237 & 102. & 493.503 & 13.3 & 422.474 & 3.7 \\
& & 532.870 & 2.0 & & \\
\hline & & 528.118 & 2.3 & & \\
\hline
\end{tabular}

Table I.NI transition probabilities $\left(A_{s i} 10^{5} \mathrm{sec}^{-1}\right)$

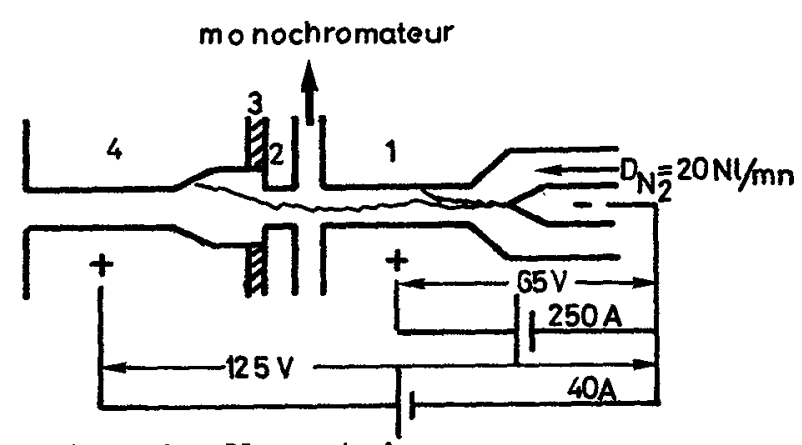

Figure 1 - Plasma device

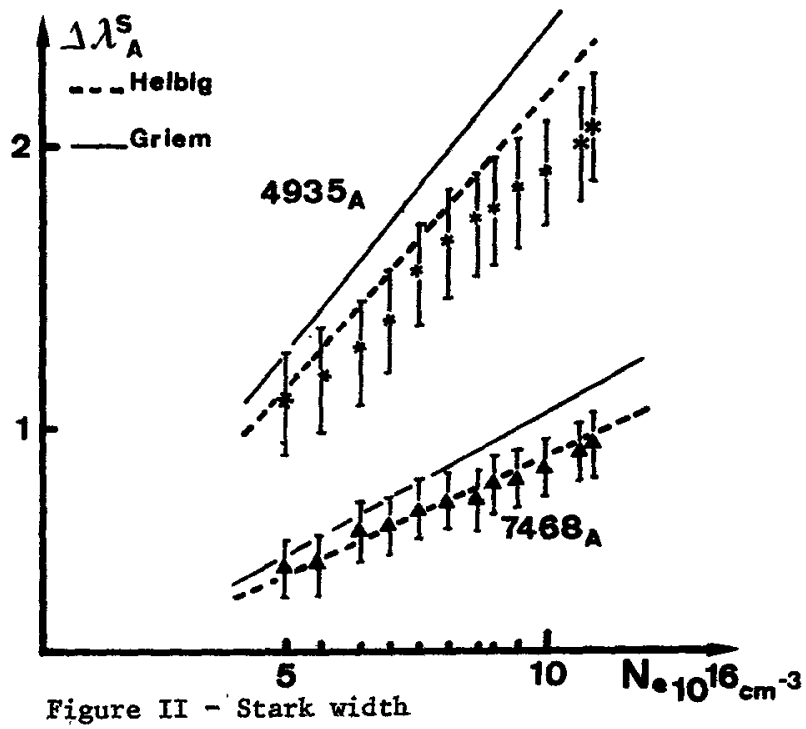

